\title{
Postharvest Fungal Spoilage of Some Citrus Fruits
}

\author{
Mohammed Bashir ${ }^{*}$, Fatima A. Hamza, Musa Sale Pukuma \\ Department of Microbiology, Modibbo Adama University of Technology, Nigeria
}

Received March 18, 2020; Revised April 19, 2020 ; Accepted April 26, 2020

Copyright $@ 2020$ by authors, all rights reserved. Authors agree that this article remains permanently open access under the terms of the Creative Commons Attribution License 4.0 International License

\begin{abstract}
This study was designed to ascertain the different types of fungal flora that are associated with spoilage of citrus fruits such as lime, lemon and sweet orange after harvesting the fruits. Fungi were isolated from the spoilage fruits under using standard laboratory techniques and appropriate media. Pure cultures of the isolates were obtained, colonial and morphological characteristics of the isolates identified based on the morphological and microscopic characteristic. The study revealed that several species of fungi were found to be associated with the spoilage of different types of citrus fruits. However, the most predominant fungi isolated were Aspergillus niger with (25.90\%) in lime, (21.5\%) in lemon and $(23.38 \%)$ sweet lemon. However, a total number of 286 fungi were isolated with (40.56\%) fungi in lime, followed by lemon with (32.52\%) and the least is sweet lemon with (26.92\%). The pathogenicity test revealed that the healthy citrus fruits injected with isolated fungi from spoiled citrus fruits shows similar growth characteristics to the original diseased sample and the result showed that Aspergillus niger has the highest diameter zone of spoilage, with $15.5 \mathrm{~mm}$ in fresh lime, $14.5 \mathrm{~mm}$ in fresh lemon and $5.0 \mathrm{~mm}$ in sweet orange. Proper agricultural and handling practices can reduce the effects.
\end{abstract}

Keywords Postharvest, Spoilage of Fruits, Citrus Fruits, Pathogenicity Test, Fungal Spoilage, Fungal Counts

\section{Introduction}

Fruits are excellent sources of minerals, vitamins and enzymes. They are easily digested and bring about a cleansing effect on the blood and the digestive tract. Hence, the ailments usually caused by the consumption of unnatural foods can easily be treated with fruits (most especially citrus) [1]. Apart from being a very good food digestive element, citrus fruits are also used for medicinal purposes [2]. Citrus fruits widely used as edible fruits belonging to citrus family and related genera of the family Rutaceae (Orange family) [3]. Citrus been a perishable agricultural products is susceptible of attack by microorganisms most especially fungi. Sweet oranges are susceptible to many fungal diseases that can cause severe economic losses. These diseases include sweet orange scab, citrus black spot disease and powdery mildew [4, 5]. Citrus spp. have been identified with different spoilage organisms, some can be macro-organisms and other microorganisms. The tendency of the spoilage may also vary according to the spoilage agents. In most cases, Citrus are exposed to sunlight causing oxidation of the major nutrients in the fruits. These conditions may be accompanied by alterations in taste, smell, appearance or texture due to the activities of spoilage microorganisms [6]. The fruits contain high levels of sugars and their low pH values make them particularly desirable to fungal spoilage.

Most citrus fruits are, in association with a variety of bacteria, and fungi, but due to environmental condition, only a small proportion of the kind of microorganism(s) present will be able to grow rapidly and cause its deterioration [7]. According to Tafinta et al. [8] postharvest losses and decay of citrus fruits can be traced to infections that occur either between flowering and fruit maturity or during harvesting and subsequent handling and storage activities.

The commercial loss from decay could reach $30-50 \%$ in some susceptible citrus cultivars [9]. The citrus fruit is attacked by several pathogens from bloom to harvesting stage and subsequently by post-harvest pathogens that affect the production of the crop and considerably deteriorate the fruit quality. Losses caused as a result of post-harvest diseases caused by various pathogens account for nearly $50 \%$ of the total waste of citrus fruits. Most postharvest pathogens (Penicillium, Alternaria, Diplodia, and Phomopsis) are opportunistic pathogens and invade through wounds. Micro-organisms are quite selective in their 1host tissues and $\mathrm{pH}$. Citrus fruits have a $\mathrm{pH}$ lower than 4 , so most of the fungi attack these fruits $[3,10]$. This study was intent to assess fungi associated with the spoilage of citrus fruits (lime, lemon and sweet oranges). 


\section{Materials and Methods}

\subsection{Samples Collection}

Ninety (90) spoiled citrus fruits were collected in Jambutu markets in Jimeta metropolis of Adamawa state, Nigeria and thirty healthy citrus fruits were also collected for the pathogenicity test after the isolation of the fungi. All the samples collected were placed in a sterile polythene bags separately and labelled appropriately and transported to the laboratory for the fungal isolation.

\subsection{Isolation of Fungi from Some Citrus Fruits}

Isolation of fungi from citrus fruits of lime, lemon and sweet orange, each spoiled citrus fruits were surface sterilized with cotton wool soaked in $70 \%$ alcohol. The fruits were cut out into small segments (3mm diameter) using sterilized scalpel, the segments of the spoiled citrus fruits was then plated on solidified potato dextrose agar plates. The inoculated plates were incubated at $28 \pm 30^{\circ} \mathrm{C}$ for 7days as described by Simmons [11]. From the incubated plates the different fungal isolates with different colorations were observed. The fungal colonies that emerged were continuously sub-cultured in order to obtain a pure culture of the fungal isolates [12].

\subsection{Identification of Fungal Isolates}

The one to four weeks pure cultures of the fungal isolates were identified using cultural and morphological features such as colony growth pattern, conidial morphology and pigmentation, by slide culture techniques [13]. A small portion of the aerial mycelia from the representative culture was picked using a sterile inoculating needle containing a drop of lactophenol cotton blue and place on glass slide and the slide was first viewed under the light microscope with (x10) and then with (x40) objective lens to detect spores, hypha and other special structures. Several fungi were isolated and they were subcultured several times to obtain a pure culture. Morphological and cultural characteristics and appearance of the isolated fungi were used for the identification of the fungi $[14,15,16]$.

\subsection{Pathogenicity Test}

Pathogenicity or decay test was done in order to know if the isolated fungi were responsible for the spoilage of citrus fruits.

Healthy fruits were surface sterilized with $75 \%$ ethanol $1 \mathrm{~min}$ and then dried under sterilized condition. Cylindrical plug tissues were cut out from the fruits using a sterilized 2mm sized corked borer. Agar disc containing one-week old culture each of fungi isolated from the spoiled fruits were aseptically placed in the holes cut out from the fresh healthy fruits, they were then covered and sealed off by means of petroleum jelly. The inoculated samples and the control were placed in sterile polythene bags and incubated at $28 \pm 3^{\circ} \mathrm{C}$ for 14 days. The severity of the diseases caused by the fungi on the fresh and healthy fruits was observed after 14days of incubation. The diameter of the rotten portion of the citrus fruits was measured and recorded. The fungi was later re-isolated from the inoculated fruits and compared with the initial isolates [17].

\subsection{Statistical Analysis}

The data obtained in this study were statistically analysed by using Mac chi-square and oneway ANOVA method of analysis to determine the significant level at $\mathrm{p} \leq$ 0.05 . The result was considered statistically significant when the p value is less than or equal to 0.05 otherwise it is not significant.

\section{Results}

\subsection{Total Fungal Counts of Some Citrus Fruits Samples}

Table 1 shows the result of the total fungal count of the entire three samples. The result revealed that lime has the highest number of isolates with 116 (40.56\%) followed by lemon with $93(32.52 \%)$ and the least is sweet lemon with 77 (26.92\%). The result of this study also revealed that amongst the citrus fruits tested lime is more susceptible to fungal spoilage after harvest.

Table 1. Total Fungal Counts of the Citrus Fruits Samples (Lime, Lemon and Sweet Orange)

\begin{tabular}{|c|l|c|c|c|}
\hline S/N & Sample & $\begin{array}{c}\text { No of } \\
\text { Sample }\end{array}$ & $\begin{array}{c}\text { No of } \\
\text { Isolates }\end{array}$ & $\begin{array}{c}\% \\
\text { Frequency }\end{array}$ \\
\hline 1 & Lime & 30 & 116 & 40.56 \\
\hline 2 & Lemon & 30 & 93 & 32.52 \\
\hline 3 & $\begin{array}{l}\text { Sweet } \\
\text { Orange }\end{array}$ & 30 & 77 & 26.92 \\
\hline & Total & $\mathbf{9 0}$ & $\mathbf{2 8 6}$ & $\mathbf{1 0 0 \%}$ \\
\hline
\end{tabular}

$x^{2}=1.923, p=0.589$

\subsection{Percentage Frequency Distribution Fungi Isolated from Citrus Fruits}

The frequency distribution of the fungi isolated from the three citrus fruits (Lime, Lemon and Sweet Orange) was presented in Table 2. From all the samples, Aspergillus niger was found to have the highest with $30(25.90 \%)$ in lime, 20(21.5\%) in lemon and 18(23.38\%) sweet lemon. Followed by Aspergillus flavus with 18(15.52\%) in lime, $18(19.35 \%)$ in lemon and 12(15.58\%) in sweet orange, and the least were Colletotrichum spp., Curvularia spp., Alternaria and Penicillium spp. with 1 (0.86\%) in lime, Colletotrichum spp. with $1(1.07 \%)$ in lemon and Alternaria spp., Diplodia spp. Curvularia spp. with $1(1.30 \%)$ in sweet lemon. 
Table 2. Percentage Frequency Distribution Fungi Isolated from Citrus Fruits

\begin{tabular}{|c|l|c|c|c|c|c|c|}
\hline & & \multicolumn{2}{|c|}{ Lime } & \multicolumn{2}{c|}{ Lemon } & \multicolumn{2}{c|}{ Sweet Orange } \\
\hline S/N & Isolate & $\begin{array}{c}\text { No of } \\
\text { Organisms }\end{array}$ & \% Frequency & $\begin{array}{c}\text { No of } \\
\text { Organisms }\end{array}$ & \% Frequency & $\begin{array}{c}\text { No of } \\
\text { Organisms }\end{array}$ & \% Frequency \\
\hline 1 & Aspergillus niger & 30 & 25.90 & 20 & 21.5 & 18 & 23.38 \\
\hline 2 & Aspergillus flavus & 18 & 15.52 & 18 & 19.35 & 12 & 15.56 \\
\hline 3 & Aspergillus fumigatus & 13 & 11.20 & 15 & 16.12 & 06 & 7.79 \\
\hline 4 & Aspergillus terreus & 10 & 8.62 & 10 & 10.78 & 07 & 9.09 \\
\hline 5 & Fusarium oxsyporum & 06 & 5.17 & 05 & 5.38 & 07 & 9.09 \\
\hline 6 & Mucor piriformis & 09 & 7.76 & 05 & 5.38 & 06 & 7.79 \\
\hline 7 & Absidia spp. & 07 & 6.03 & 04 & 4.30 & 05 & 6.50 \\
\hline 8 & Rhizopus stolonifer & 08 & 6.89 & 03 & 3.23 & 04 & 5.19 \\
\hline 9 & Torulopsis candida & 01 & 0.86 & 03 & 3.23 & 01 & 1.30 \\
\hline 10 & Mucor hiemalis & 07 & 6.03 & 05 & 3.23 & 04 & 5.19 \\
\hline 11 & Penicillium spp. & 01 & 0.86 & 01 & 1.07 & - & - \\
\hline 12 & Alternaria spp. & 01 & 0.86 & 01 & 1.07 & 01 & 1.30 \\
\hline 13 & Diplodia spp. & 02 & 1.72 & 01 & 1.07 & 01 & 1.30 \\
\hline 14 & Guignardia citricarpa & 01 & 0.86 & 02 & 2.15 & 02 & 2.60 \\
\hline 15 & Curvularia spp. & 01 & 0.86 & 01 & 1.07 & 01 & 1.30 \\
\hline 16 & Colletotrichum spp. & 01 & 0.86 & 01 & 1.07 & 02 & 2.60 \\
\hline & Total & $\mathbf{1 1 6}$ & $\mathbf{1 0 0 \%}$ & $\mathbf{9 3}$ & $\mathbf{1 0 0 \%}$ & $\mathbf{7 7}$ & $\mathbf{1 0 0 \%}$ \\
\hline
\end{tabular}

$\mathrm{P}=0.507, \mathrm{p}=0.119, \mathrm{p}=0.592$

Table 3. Pathogenicity Test on Fresh Healthy Citrus Fruits in Diameter (mm)

\begin{tabular}{|l|l|l|l|l|}
\hline S/N & Organisms & Lime $(\mathbf{m m})$ & Lemon $(\mathbf{m m})$ & Sweet Orange (mm) \\
\hline 1 & Aspergillus niger & 15.50 & 14.50 & 5.00 \\
\hline 2 & Aspergillus flavus & 12.00 & 12.50 & 3.00 \\
\hline 3 & Aspergillus terreus & 9.00 & 11.50 & 4.50 \\
\hline 4 & Aspergillus fumigatus & 11.00 & 11.00 & 3.00 \\
\hline 5 & Mucor piriformis & 7.00 & 10.00 & 3.50 \\
\hline 6 & Rhizopus stolonifer & 7.50 & 9.50 & 3.50 \\
\hline 7 & Mucor hiemalis & 7.50 & 9.00 & 3.00 \\
\hline 8 & Absidia spp. & 6.00 & 9.50 & 3.50 \\
\hline 9 & Torulopsis candida & 3.00 & 7.00 & 2.50 \\
\hline 10 & Fusarium oxsyporum & 6.00 & 6.00 & 3.50 \\
\hline
\end{tabular}

$x^{2}=5.252, p=0.998$

\subsection{Pathogenicity Test on Fresh Healthy Citrus Fruits in Diameter (mm)}

The result of pathogenicity test carried out on fresh healthy citrus fruits (Lime, Lemon and Sweet Orange). It revealed that the healthy fruit which was injected with initially isolated fungi from spoiled citrus fruits shows similar growth characteristics to the original diseased sample which revealed that Aspergillus niger has the highest diameter zone of spoilage, with $15.5 \mathrm{~mm}$ in fresh lime, $14.5 \mathrm{~mm}$ in fresh lemon and $5.0 \mathrm{~mm}$ in sweet orange. This was followed by Aspergillus flavus with $12.0 \mathrm{~mm}$ in fresh lime, $12.5 \mathrm{~mm}$ in fresh lemon while in sweet lemon it is followed by Aspergillus terreus with $4.5 \mathrm{~mm}$. In lime and sweet orange the least was found to be Torulopsis candida with $3 \mathrm{~mm}$ and $2.5 \mathrm{~mm}$ respectively, while in lemon the least was found to be Fusarium oxsyporum with $6 \mathrm{~mm}$ as described in Table 3.

\section{Discussion}

The major orange deports in Jimeta metropolis is Jambutu markets along Jimeta bye pass where citrus fruits dealers and suppliers come to sell their products to petty traders and the goods were distributed by petty traders 
within the metropolis. Several fungal species were identified in this study and they were found to be associated with spoilage of citrus fruits (lime, lemon and sweet orange) this is because the organisms isolated from spoiled citrus fruits were isolated after pathogenicity test. These groups of fungi include Alternaria spp., Penicillium spp., Aspergillus niger, Aspergillus flavus, Aspergillus fumigatus, Aspergillus terreus, Fusarium oxsyporum, Mucor piriformis, Absidia spp., Rhizopus stolonifer, Torulopsis candida, Mucor hiemalis, Colletotrichum spp., Curvularia spp. Similar organisms were isolated by [18] on their work isolation and identification of postharvest spoilage fungi associated with sweet oranges (Citrus sinensis) traded in Kano metropolis. The amount of sugar in these fruits and also the high temperature in Jimeta, Yola can facilitates the growth and development of these fungi on citrus fruits and causes the spoilage of these fruits.

Amongst the fungal isolates, high percentages were found in lime with $116(40.56 \%)$ and it signifies that this fruits is more susceptible to fungal infection and is contaminated with many types of fungi that lead to the spoilage of the spoilage of lime fruits. Aspergillus niger was found to have the highest frequency distribution with $30(25.90 \%)$ in lime, $20(21.5 \%)$ in lemon and $18(23.38 \%)$ sweet lemon among all the three types of samples collected and analysed in this study. However, several also reported Aspergillus niger having the highest frequency distribution amongst fungi associated with the spoilage of citrus fruits. Onuorah et al. [19] reported that Aspergillus niger had the highest percentage distribution of 11(27.5\%). Furthermore, [20] also reported that Aspergillus niger was found to have the higher rate of occurrence among the sample collected in their study area with 43(57.23\%). The higher frequency of Aspergillus niger in several of these studies may be attributed to the facts that Aspergillus niger is fast growing organisms and it grow faster than most of the fungi isolated in the study.

Moreover, the presence of these fungi in citrus fruits (lime, lemon and sweet orange) may be as a result of their ability to produce resistant spores as reported by [18] that spores of Aspergillus are more resistant to high temperature, and Jimeta, Yola has a high temperature which provide a good environment for the organisms to grow. This fungi and their spores can contaminated the fruits right from the farmland and sometimes during harvesting of the fruits and even during storage especially when there is poor handling of the fruits by the workers.

Apart from Aspergillus spp., Alternaria spp., Fusarium spp., Rhizopus stolonifer, Absidia spp. and Mucor spp. were also isolated in this study. Because these fruits contain sugar and a lot of water contents, organisms such as Fusarium spp. that need moisture can live and grow successfully and causes the spoilage of citrus fruits.

\section{Conclusions}

Conclusively, the results of the present study have revealed the spoiled oranges were mainly contaminated with several fungal species such as Aspergillus spp., Mucor spp., Rhizopus spp., Absidia spp., Torulopsis candida, Fusarium spp. Some citrus fruits were observed to have been contaminated with more than one fungal organism. Presence of these organisms in citrus fruits, most especially Aspergillus spp. poses a serious threat to the health of consumers because the organisms produce spore and even mycotoxins which are lethal when consumed. Most of the fungi isolated were observed to be able to re-infect healthy oranges within short time, when they are introduced to the healthy ones.

\section{Recommendation}

This study shows that citrus fruits can be easily contaminated with the introduction of fungi, therefore proper hygiene of the environment where the citrus fruits are to kept should be encourage. Also the harvesting process should be done proper and carefully to avoid the introduction of organisms (fungal) into the citrus fruits. Finally buyers of citrus fruits should carefully and critically observe the fruit before purchase; white and black spots should be observed as it shows signs of fungal infestation.

\section{REFERENCES}

[1] Taiwo, T.A. Production of fruits, Vegetables, Grains, Legumes. Root crops in Nigeria; Problems and Prospects. University Press, 1 pp. 9. 2005.

[2] Chase, W.G. Production of Citrus Fruits. Proceeding of International Society of Citriculture, 3:1365-1373. 2007.

[3] Milind, S.L. Citrus Fruit Biology, Technology and Evaluation. First ed. book, Copyright (c) Elsevier Inc. All Rights Reserved Academic Press. 2008.

[4] Sposito, M.B., Amorim, L., Bassanezi, R.B., Yamamoto, P.T., Felippe, M.R., Czermainski, A.B.C. Relative Importance of Inoculum Sources of Guignardia citricarpa on the Citrus Black Spot Epidemic in Brazil. Crop protection, 30(12): 1546-1552. 2011 doi: 10. 1016/j.cropro .2011.08.007.

[5] Madhurababu Kunta, John Rascoe, Patricia B. de Sa, Lavern W. Timmer, Mary E. Palm, John V. da Graça, Robert L. Mangan, Nasir S.A. Malik, Bacilio Salas, Aditi Satpute, Mamoudou Sétamou and Mani Skaria. Sweet Orange Scab with A New Scab Disease "Syndrome" of Citrus in the USA Associated with Elsinoë australis, Tropical Plant Pathology, 38(3): 203-212. 2013. 
[6] Akinmusire. O.O. Fungal Species Associated with the Spoilage of some Edible Fruits in Maiduguri, North Eastern, Nigeria; Advances in Environmental Biology, 1.5 (1): 157-161. 2011.

[7] Alfred II, Patrick ONP. Food Values of some Tropical Fruits and Vegetables: In the Integrated Food Science and Technology for Tropics 2nd Edition pp. 305-306. 1985.

[8] Y. Tafinta, K. Shehu, H. Abdulganiyyu, A.M. Rabe, A. Usman. Isolation and Identification of Fungi Associated with the Spoilage of Sweet Orange (Citrus sinensis) Fruits in Sokoto State. Nigerian Journal of Basic and Applied Sciences, 21(3):193-196. 2013.

[9] Porat, R., Daus, A., Weiss, B., Cohen, L., Fallik, E. and Droby, S. Reduction of Postharvest Decay in Organic Citrus Fruit by a Short Water Brushing Treatment. Postharvest Biology and Technology, 18(2): 151-157. 2000. DOI: 10.1016/S0925-5214(99)00065-4

[10] Mary O, Mike, M. Mike McClure and Zhongguo, X. Diseases of Citrus in Arizona. Arizona Cooperative Extension pp. 1-10. 2000.

[11] Simmons, E.G. Alternaria themes and variations Mycotaxon, 83: 127-145. 2002.

[12] Alberto Munoz, Belen Lopez-Garcia, Luis Gonzalez-Candelas and Jose F. Marcos. Comparative Analysis of the Sensitivity to Distinct Antimicrobials among Penicillium spp. Causing Fruit Postharvest Decay, Phytopathol Mediterr, 50(3): 392-407. 2011. DOI: 10.1460 1/Phytopathol_Mediterr-9309

[13] Oyeleke, A. and Manga, S.B. Essential of Laboratory Practice, $3^{\text {rd }}$ edition. Tobest publishers, Minna, Niger State, Nigeria. 12 - 29. 2008.

[14] Ellis M.B. Dematiaceous Hyphomycetes. Commonwealth Mycological Institute, Kew, England, pp. 608. 1971

[15] Nelson P.E., Toussoum T.A., Marasas W.F.O. Fusarium Species. An Illustrated Manual for Identification. The Pennsylvania University, USA, pp. 206. 1983.

[16] Barnett H.L., Hunter B.B. Illustrated Genera of Imperfect Fungi. 4th ed. APS Press, St. Paul, Minnesota, USA, pp. 218. 1998.

[17] Ismail, M. and J. Zhang. Postharvest Citrus Diseases and their Control. Outlook on Pest Management, 15(1) 29-35. 2004. DOI: $10.1564 / 15 f e b 12$

[18] Bukar, A., Mukhtar, M.D. and Adamu, S. Isolation and Identification of Postharvest Spoilage Fungi Associated with Sweet Oranges (citrus sinensis) Traded in Kano Metropolis, Bayero Journal of Pure and Applied Sciences, 2(1):122 - 124. 2009.

[19] Onuorah Samuel1, Obika Ifeanyi, Okafor Ugochukwu. Filamentous Fungi Associated with the Spoilage of Postharvest Sweet Orange Fruits (Citrus sinensis) Sold in Awka Major Markets, Nigeria, Bioengineering and Bioscience, 3(3): 44-49. 2015. DOI: 10.13189/bb.2015.030 303

[20] Nasiru, AM., Salau, IA. and M. Yakubu. Fungi Associated with Spoilage of Citrus sinensis in Fruits and Vegetables Market, Sokoto, Nigeria, Global Advanced Research Journal of Agricultural Science, 4(12) pp. 919-922, 2015
Special Anniversary Review Issue. http://garj.org/garjas/ho me 